LIAMES, Campinas, SP, v. 20, 1-27, e020005, 2020

\title{
Standard negation in Chibchan ${ }^{1}$
}

\author{
Johan van der Auwera \\ University of Antwerp, Belgium \\ https://orcid.org/0000-0001-9222-2994 \\ Olga Krasnoukhova \\ University of Antwerp, Belgium \\ https://orcid.org/0000-0002-1953-7954
}

\begin{abstract}
This paper surveys the form and the position of the negators of declarative verbal main clauses in the Chibchan languages. It attempts to describe the similarities and the differences, and it ventures hypotheses about the diachrony, primarily with an appeal to the Jespersen and Negative Existential Cycles. It sketches if and how the negators fit more general areal patterning, in particular, the Columbian Central American linguistic area. KEYwORDs: Negation; Jespersen Cycle; Negative Existential Cycle; Columbian Central American linguistic area.
\end{abstract}

RESUMEN: Este artículo presenta una panorámica de la forma y la posición de los negadores de oraciones principales declarativas en las lenguas chibchas. Pretende describir las similitudes y las diferencias, y propone hipótesis sobre la diacronía, principalmente en relación con el Ciclo de Jespersen y el Ciclo Existencial Negativo. Apunta de qué manera los negadores encajan en mecanismos más amplios de organización areal, en particular en el área centroamericana colombiana.

Palabras Clave: Negación; El Ciclo de Jespersen; El Ciclo Negativo Existencial; El Área Colombiano-Centroamericana.

\section{Introduction}

The Chibchan languages show a lot of variation in the expression of negation of declarative verbal main clauses, henceforth, with Payne (1985) and Miestamo (2005), 'standard negation'. This variation concerns both the form and the position of the negative marker. The variation with respect to position, i.e., the question whether the negator is preposed or postposed with respect to the verb, either as an affix or as a particle, is a little surprising, given that the Chibchan languages are hypothesized to be part of a

${ }^{1}$ This study derives from a larger study on negation in the languages of South America, funded by the Research Foundation Flanders. We are very grateful to José Manuel Murillo Miranda and Diego Quesada, both at the National University of Costa Rica, and the two anonymous reviewers for their most helpful comments.

DOI: http://dx.doi.org/10.20396/liames.v20i0.8658401 
Columbian Central American ('CCA') linguistic area (Constenla Umaña 1991), and that this area is supposed to be characterized by the predominance of postposed negation (Constenla Umaña 1991: 111-112, 200). Of the 32 CCA languages that Constenla Umaña (1991) studied, 14 are Chibchan and only eight of these have postposed negation. Of the remaining six languages five have preposed negation and one has both postposed and preposed negation. The languages are listed in Table 1. Here and elsewhere we use the language names of the Glottolog (Hammarström et al. 2019) as well as its language codes ('Glottocodes'). ${ }^{2}$ In Table 1 we add the names that Constenla Umaña (1991) used, when they differ from the Glottolog names.

Table 1: The position of the standard negator (Constenla Umaña 1991)

\begin{tabular}{c|c|c} 
preposed & postposed & $\begin{array}{c}\text { preposed and } \\
\text { postposed }\end{array}$ \\
\hline Maléku Jaíka (male1297) (= Guatuso) & Pech (pech1241) (= Paya) & \\
Bribri (brig1243) & Boruca (boru1252) & \\
Cabécar (cabe1245) & Kuna (kuna1280) (= Cuna) & Rama \\
Ngäbere (ngab1239) (= Movere) & Cogui (cogu1240) (= Cágaba) & $\begin{array}{c}\text { (rama1270) } \\
\text { Bokotá (boko1272) (= Bocotá) }\end{array}$ \\
& Arhuaco (arhu1242) (= Bíntucua) & \\
\hline 5 & Tunebo (tune1260) & 1
\end{tabular}

For the non-Chibchan CCA languages the feature scores much better: out of 18 nonChibchan languages 14 have postposed negation. Assuming that the overarching CCA hypothesis is correct, one could conclude that the position of the standard negator is not a good diagnostic for this area. This is also suggested by the absence of this feature in Quesada (2007: 22-31). Furthermore, in a brief section on negation, Quesada (2007: 7677) says that Chibchan negation can be preposed or postposed and he doesn't comment on the claim by Constenla Umaña (1991). Still, 20 years after Constenla Umaña (1991) proposed the CCA area, he kept the feature in his later work (Constenla Umaña 2012: 421).

In this paper we study the position and form of the standard negator in some detail. We also look at four more Chibchan languages, viz. Barí (bari1297), Chimila (chim1309), Malayo (mala1502) and Sabanero (saba1272), and for some languages we mention dialect differences. Our account is based on existing, language-particular studies. We offer no empirical novelty. The main merit of the paper is two-fold: we offer a synthesis of the available data on negation in the Chibchan family with the aim of a comprehensive comparison, and we present a number of hypotheses, at least for some languages, as to

${ }^{2}$ The Glottolog system is becoming a standard, but that does not mean that it is fully felicitous for Chibchan, as Diego Quesada (p.c.) pointed out to us. 
why the negators are preposed or postposed. While the focus is on standard negation, we discuss nominal and existential negation for some languages, the reason being that standard negation is likely to have its origin in these. To make diachronic claims we cannot count on descriptions of earlier stages of the languages. Instead we rely on what typology can tell us about general changes affecting negation, complemented by synchronic comparison of the closely related Chibchan languages. For some issues this method and the amount of available evidence allows for specific hypotheses. For other issues, however, the synchronic descriptions are suboptimal and our proposals remain conjectures, hopefully steering further research.

The term 'nominal negation' is used here for a variety of things. First of all, we include both privative and ascriptive negation strategies. Privative negation is illustrated in pseudo-English (1).

(1) Yesterday he was without swimming.

'Yesterday he didn't swim.'

Under ascriptive negation we allow the more strict 'substantival' negation strategy - swimmer in (2a-b) being a noun, but also the 'adjectival' negation strategy - taking the participle in (2c-d) as an adjectival form, and we include both expressions that ascribe a negative property ( $2 \mathrm{~b}$ and $2 \mathrm{~d}$ ) and ones that do not ascribe a positive property ( $2 \mathrm{a}$ and $2 \mathrm{c}$ ).

(2) a. Yesterday he was not a swimmer.

b. Yesterday he was a not-swimmer.

c. Yesterday he was not swimming.

d. Yesterday he was non-swimming.

'Yesterday he didn't swim.'

The reason why we take all of these together is that we often cannot tell them apart. Of course, if we can or if some linguist does try, we will make that clear. The processes in which nominal negation can develop into standard negation are only beginning to be studied (van der Auwera \& Krasnoukhova 2020: 109-110; also Michael 2014 for privative negation, and Krasnoukhova \& van der Auwera 2019 for ascriptive negation). The development from existential negation to standard negation, the so-called 'Negative Existential Cycle', is better studied (Croft 1991; Veselinova 2014, and Hamari \& Veselinova (eds.) 2020), but, as we will see, it is not always easy to separate an existential from a privative negation.

In section 2 we discuss the postposed negators and in section 3 the preposed ones. Section 4 attempts to offer some generalizations, and section 5 is the conclusion. In the rest of the paper we don't give the glottocodes anymore, but for 'Core Chibchan' we will mention the main branch a language belongs to, i.e., Votic, Eastern or Western Isthmic and Northern or Southern Magdalenic. The internal branching of Chibchan in (3) is adopted from Glottolog. ${ }^{3}$ Glosses and abbreviations, though based on the sources, have

${ }^{3}$ We disregard Antioquian (anti1242), which Glottolog lists as 'unclassified' and for which we have no data. We also have no data for Doracic Isthmic. 
been standardized and are meant to reflect our analysis. We retain the orthography of the sources. Map 1 shows geographic location of the Chibchan languages, as given in Glottolog. Languages that we discuss in the paper are marked in bold on the map.

(3)
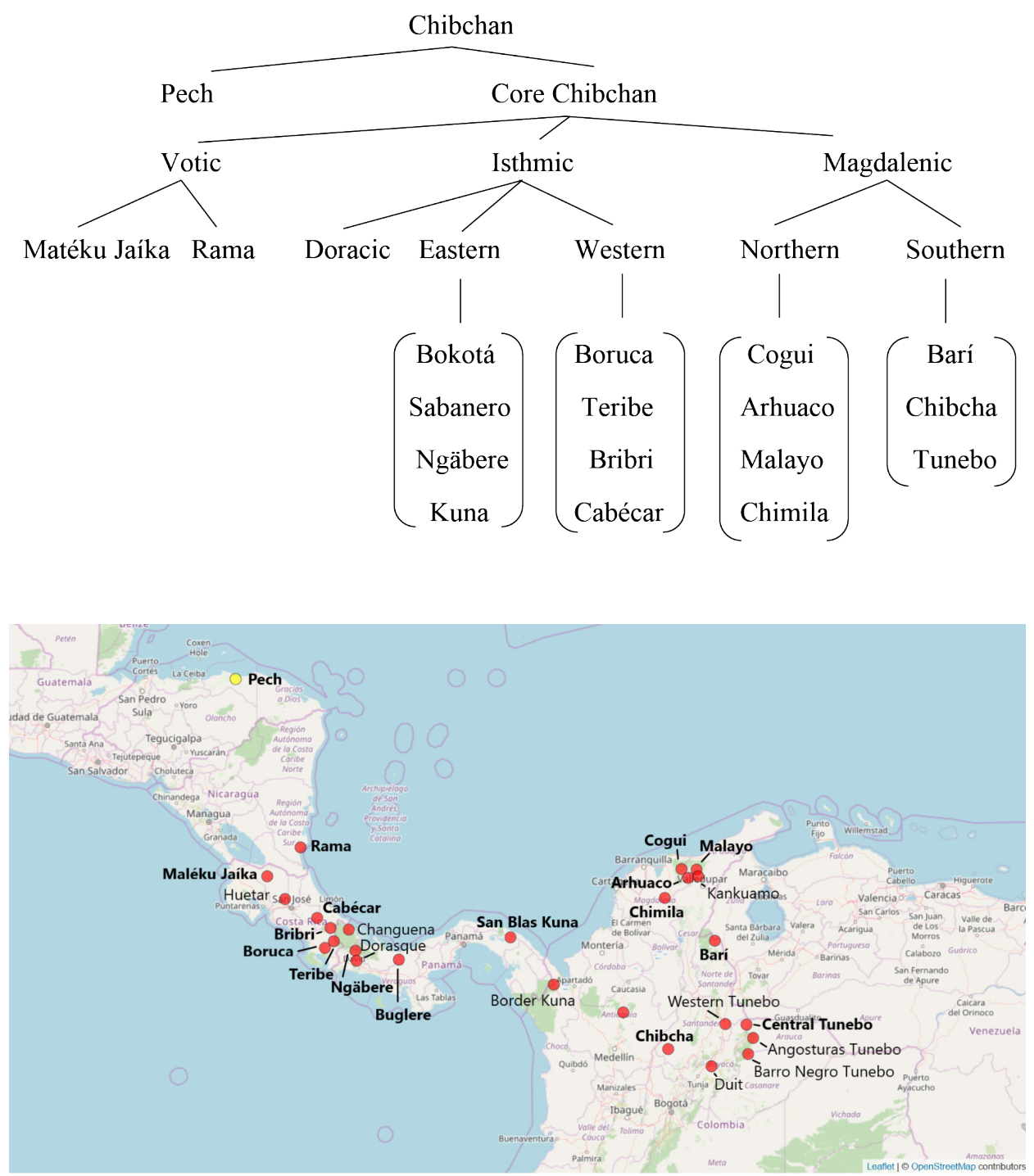

Map 1: Geographic location of Chibchan languages (Hammarström et al. 2019), base map provided by OpenStreetMap [openstreetmap.org]). Note that the Bokotá and Sabanero varieties are represented on the map with Buglere. 


\section{Postposed negators}

As mentioned above we encounter a great variation in the form of the negation markers. In this section we focus on postverbal negators and consider possible formal correspondences.

\subsection{The Boruca suffix $-i^{2}$ shi and possible cognates}

\subsubsection{Boruca -i'shi, Tunebo -ti and Barí -shi}

We start with negative suffixes in Boruca (Isthmic) and Tunebo and Barí (both Magdalenic), because they are the only ones for which, as far we know, an explicit, though tentative cognancy claim has been made (see below). In Boruca the negator is a suffix $-i{ }^{\text {S }}$ h $i$. It is followed by tense-aspect suffixes and merges with them. For instance, in the present tense $-i^{2}$ shi combines with $-r a$ and the merger gives $-i^{2}$ sha (Quesada Pacheco 2018: 128).

(4) Boruca (Quesada Pacheco 2018: 128)
Át qui i dena-i'sha.
$1 \mathrm{SG}$ DET 3 expect-NEG.PRS

'I do not expect it.'

According to Quesada Pacheco (2018: 128) it is highly likely ('muy probable') that this negator derives from a nominal negator, in particular, an adjectival one (Quesada Pacheco 2018: 70). His argument is that the tense-aspect suffixes ${ }^{4}$ are added to the root. In negation, they are added to the root plus the negator, which can thus be seen as a derived root.

(5) Boruca (Quesada Pacheco 2018: 128)
a. sodíj-ra
do-PRS
b. sodíj-i'sha $<$ sodíj-i'sh-ra
do-NEG.PRS do-NEG-PRS

In reality ('en realidad') teg-i'sha 'does not speak' is rather 'is not speaking' or 'is lacking in speaking' (Quesada Pacheco 2018: 128). Note that the two paraphrases are not exactly identical: the first is ascriptive and the second is privative. ${ }^{5}$ If Quesada Pacheco (2018) is right, we have a standard negator that has a nominal origin or could still be

${ }^{4}$ Quesada Pacheco (2018: 128) calls these tense-aspect suffixes 'affirmative'. We have two reasons to prefer our terminology. First, these suffixes come in a paradigm with different tense-aspect values (present/ future, imperfect, perfect, plusquamperfect). Second, Quesada Pacheco (2018) contrasts 'affirmative' suffixes with negative ones. However, the negative ones are no less tense-aspect-sensitive than the affirmative ones, so if these suffixes are called 'affirmative', the negative ones would have to be called 'affirmative-negative'.

${ }^{5}$ This illustrates our reason for using the term 'nominal negation' in a wide sense encompassing both negation types. 
nominal, and we also have an explanation why the negator is suffixal: this kind of nominal negator is part of the adjectival derivation system and in this system we only have suffixes (Quesada Pacheco 2018: 65). Of course, it is not excluded that this negative suffix is verbal in origin. It is common cross-linguistically that standard negators originate in nonexistence verbs (Croft 1991; Veselinova 2014), (cf. also sections 3.1 to 3.3). Tense-aspect suffixes would have belonged to the negative verbal root initially.

Quesada (2004: 367) tentatively suggests that Boruca $-i^{\text {P }}$ shi (spelled as -shi in Quesada 2004) has cognates in two Magdalenic languages, viz. Tunebo -ti and Barí -shi. The Tunebo variety in (6) is Central Tunebo.

(6) Central Tunebo (Marquez et al. 1988: 121)

As abrá Bokutra bi-tí-bi-ro. ${ }^{6}$

my mother Bogotá go-NEG-PST-3

'My mother did not go to Bogotá.'

(7) Barí (Quesada 2004: 367)

Nay ba-kag-bishro-ni.

1SG 2SG-wait- NEG.PRS -1SG

'I don't wait for you.'

For Central Tunebo, Marquez et al. (1988: 122, 158) explicitly say that the negator combines with the 'normal' root to build a negative root. The latter is then followed by tense marking, like in Boruca; but, unlike in Boruca, there is also person marking. In Barí, too, tense and person marking follow the negator; there is no claim on whether or not the addition of the negator to the stem makes a 'new' stem. In any case, if the nominal explanation for the suffixal nature of the negator holds for Boruca, it could hold for Barí and Tunebo, too.

Before we look for further cognates, it is of note that the Tunebo situation is a bit more complicated. First, next to the - $t i$ strategy, Tunebo also uses a privative strategy, with a privative postposition bar, which 'easily verbifies' (Marquez et al. 1988: 62) ${ }^{7}$ it is especially used in the future (Marquez et al. 1988: 124).

(8) Central Tunebo (Marquez et al.1988: 124, 124)
a. Ara iri bar
'I woke up without a meal.'
b. Asra kamá-bar-kera.
1sG sleep-NEG-FUT
'I will not sleep.' kuanjá-ro.

today meal without woke.up-1

${ }^{6}$ The analysis of -ro is not clear. Marquez et al. (1988: 12) say that -ro is a first person suffix which can also be used for the first person. For Headland (1994: 38) it is a declarative suffix.

${ }^{7}$ Headland (1994: 41) treat bar as a negative existential, which is, after all, close to what a 'verbified' privative must be ('to be without'). 
Interestingly, an older account of Rivet (1924: 27-28), for a different dialect, only mentions the bar 'without' strategy, and not the $t i$ strategy; the latter is mentioned only for prohibitive negation (Rivet 1924: 28).

A second special feature about Central Tunebo is that negation is often 'reinforced' with a suffix $-i$ on the constituent before the verb (Marquez et al. 1988: 126).

(9) Central Tunebo (Marquez et al. 1988: 126)

Ajatra eb- $i$ bu-ti-ro.

1SG corn-NEG tresh-NEG-1

'I do not tresh corn.'

The $-i$ can be seen as a focus or scope marker. It also shows up in some WH-questions, where it arguably also relates to focus or scope.

(10) Central Tunebo (Marquez et al. 1988: 134)

As abán bí-i-ka?
my mother

'Who is my mother?'

In any case when $-i$ occurs in a negative clause, Marquez et al. (1988: 126) treat it as an echo or an enforcer of a kind of 'negative concord' (van der Auwera \& Van Alsenoy 2016). If the element should be considered inherently negative, i.e., divorced from the use of what is potentially historically the same marker in WH-questions, then we are not dealing with a postposed negator in (9), but a circumverbal one. Alternatively, if the $-i$ marker of the negative clause is not considered inherently negative, then we are dealing with constructional asymmetry, in the sense of Miestamo (2005). In the description of Headland (1994: 41) $-i$ alternates with a contrastive suffix $-r a$, but while $-r a$ is glossed as contrastive, $-i$ is glossed as an inherently negative emphasis marker. Also, there is an example where it follows -bar.

(11) Central Tunebo (Headland 1994: 41)

$[\ldots]$ in beca bár-i-ra.

fast return NEG-NEG-CONT

'[...] I cannot return fast.'

All in all, it seems that $-i$ is inherently negative, which then means that a sentence like (9) illustrates a circumverbal negation.

As a final point we note that Boruca belongs to the Isthmic branch of Chibchan, one of the two big branches, and Tunebo and Barí to the Magdalenic branch. This suggests that the $i^{2}$ shi/-ti/-shi strategy is an old one, which existed before the split, possibly 3,200 years B.C. (Constenla Umaña 2012: 419).

\subsubsection{Cogui -zhé/-ža and Chibcha -za/-zha}

If Quesada's (2004: 367) suggestion is right, i.e. that Boruca -i'shi, Tunebo - $t i$ and Barí -shi are cognates, perhaps Cogui -zhé (Ortíz Ricaurte 1992: 124), -ža (Holmer 1953: 
334) or $3 a$ (Oyala Perdomo 2000:785) and Chibcha -za/-zha (Quesada Pacheco 2012: 5455) or $\check{z} a / \check{z} e / z ̌ i ~(P r e u s s ~ 1925: 381)$ are cognates too.

(12) Cogui (Oyala Perdomo 2000: 785)

$\begin{array}{ll}\text { Nuzin naga-3a-li-ku-aj } & \text { nza. } \\ \text { tomorrow come-NEG-FUT-1sG-NMLZ is } \\ \text { 'Tomorrow I won't come.' }\end{array}$

(13) Chibcha (Quesada Pacheco 2012: 54)

Muysca atabie abgu-za.

person some 3.kill.ERG.PST-NEG

'He has not killed anybody.'

Judging from example (12), ${ }^{8}$ in Cogui the negator precedes tense and person marking, like in Central Tunebo and Barí, thus, in principle, allowing a nominal negator analysis à la Quesada Pacheco (2018). But it wouldn't work for Chibcha, which has the negator after the tense-aspect marking.

Like in Central Tunebo, the Cogui $3 a$ is not the only standard negator. First, there is a -ki suffix (Preuss 1925: 382; Holmer 1953: 334; Oyala Perdomo 2000: 78).

(14) Cogui (Oyala Perdomo 2000: 785)

Kaggaba tua- $k i$ ni-gu-ku.

people see-NEG R-do-1sG

'I don't see anyone.'

Second, there are various negative existential strategies with -lili and -gali (Holmer 1953: 334) or suñ, suñzē, suñza and súngele (Preuss 1925: 383-384) and yet other forms are mentioned in Celedón (1886: 17-18). It remains unclear whether these strategies count as standard negation strategies or whether they are merely negative existential periphrastic strategies, not unlike what we see in English when we paraphrase 'I don't see anyone' with 'It is not the case that I see anyone'.

(15) Cogui (Holmer 1953: 334)

Bakan ga-gali.

meat eat-NEG

'He does not eat meat.'

\subsubsection{Terribe llëme}

In Teribe the standard negator is llëme and it is not just postposed but 'essentially clausal-final' (Quesada 2000: 103).

${ }^{8}$ This example is not perfect, for it only shows a periphrastic strategy or an 'indirect' one (in the terminology of Ortíz Ricaurte (1994: 394-395). The other examples in Oyala Perdomo (2000: 785) are not ideal either, for the negators are either -ki (14) or -la and -na, claimed to be 'variants' of $3 a$. 
(16) Teribe (Quesada 2000: 103)

$\mathrm{E}$ ma wuë llëme.

DEM fish eat NEG

'He doesn't eat fish.'

llëme might decompose into $l l \ddot{e}$ - and -me. Orthographically, llë-looks very different from the negators discussed so far, i.e., Boruca $-i^{2} s h i$, Tunebo -ti and Barí -shi, Cogui

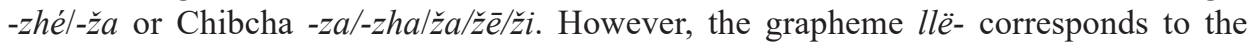
phoneme /3æ/ (Quesada 2000: 40-41), a correspondence that is better represented in the orthography of the displaced variant of Teribe referred to as 'Terraba'. ${ }^{9}$ For Terraba the negator llëme is spelled as zime (Portilla Cháves 1986: 145, 146, 168, 169, 173). Of course, in Terribe the $l l \ddot{e}$ - element is not a verbal suffix, different from the previous negators, and it combines with a -me element.

We propose that the llë part is the grammaticalized form of llëbo 'thing', mentioned in three other parts of the grammar. First, it is an indefinite and interrogative pronoun meaning 'something' and 'what' or - the decision is not relevant for our purposes - an indefinite pronoun meaning 'something' that has an interrogative 'what' use in questions (Quesada 2000: 102, 143).

(17) Teribe (Quesada 2000: 143, 102)
a. Ta pī-zong $l l \ddot{e}$.
1SG teach-IMP something
'Teach me something.'
b. Pa shäng llë shärie?
2SG POSIT:stand what do
'What are you doing?'

Second, llë is a partitive marker, making a noun mass and indefinite (Quesada 2000: $52)$.

(18) Teribe (Quesada 2000: 52)
Dlunna llë yë-y.
salt PART $^{10}$ put-1PL.INCL

'We add salt.'

Third, llë serves object demotion (Quesada 2000: 145).

(19) Teribe (Quesada 2000: 145)
a. Tawa llëbo yo-no.
1PL.EXCL things eat-PRF
'We ate things.'

${ }^{9}$ Terraba came about after a forced displacement of Teribe speakers in 1695 some 40 kilometres south in present-day Costa Rica (Portilla Cháves 2003: 7, 12).

${ }^{10}$ Quesada's gloss is 'mass', but we prefer a 'partitive' label, being closer to the description. 


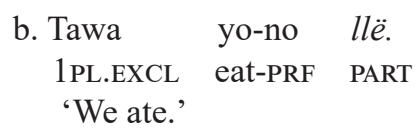

Our proposal to identify the llë bit of the negator llëme as deriving from 'something' would give it yet a fourth place in the grammar.

If the llë part derives from 'thing/something', what then is -me? Different from llë-, -me does not appear much in the grammar. However, the word for 'no longer' is ame (Quesada 2000: 104). This makes it plausible to take $m e$ as a negator. There is furthermore familyinternal, Chibchan, evidence: me shows up in Bokotá me (§3.1), Maléku Jaíka me (\$3.4) and perhaps in Rama ma (\$2.1.4). ${ }^{11}$ This way llëme presumably means 'nothing'. ${ }^{12}$ What is left now is to remind us that a development from 'nothing' to 'not' makes sense. We don't have to look further than English or, more generally, West-Germanic. In West-Germanic this development took place in sentences which didn't only contain the 'nothing' word but a standard negator as well. What happened then was that the standard negator disappeared and the 'nothing' word became the new negator (20).

$\begin{array}{clll}(20) & \text { ne } \rightarrow & \text { ne } \ldots & \text { not } \\ \text { NEG } & \text { NEG } \ldots & \text { nothing }\end{array} \quad$ not

In Latin a negative word like 'nothing' changed to a standard negator without the presence of an older negator: the standard negator ne merged with oemum 'one', becoming 'none', and the resulting noenum became the standard negator non- (21). This may have happened in Sabanero too - cf. (30b) below.

$\begin{array}{cl}(21) \text { ne } \rightarrow & \text { ne ... oenum } \\ \text { NEG } & \text { NEG ... one }\end{array} \quad \begin{aligned} & \text { non } \\ & \text { NEG }\end{aligned}$

In both cases, i.e. the Germanic and the Latin case, we can consider the development to be types of 'Jespersen Cycle' (van der Auwera; Krasnoukhova \& Vossen 2020) and in both cases 'nothing' goes to 'not' via an intermediate emphatic stage of the marker meaning 'not at all, in no way'. This scenario could also help explain why llëme is further to the right than just postposed. In Teribe, adverbials go to the right of the verbal complex (the verb with its arguments) (Quesada 2000: 93).

${ }^{11}$ A study of all negators, not just standard ones, could show a further distribution. Thus at least Gasso's (1908: 89) study of San Blas Kuna has me as the first part of a prohibitive negator mele. Forster (2011: 203) has a similar form melle.

${ }^{12}$ We find this in the Terraba example (a).

(a) Terraba (Portilla Cháves 1986: 145)

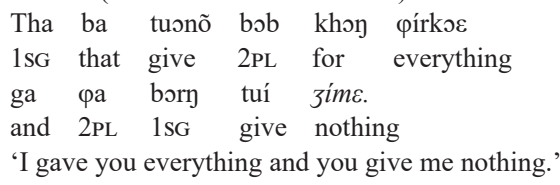




\subsubsection{Pech -tVh and Rama tahma}

If Tunebo $-t i$ is a member of the $i^{2} s h i /-t i / s h i$ cognate set, could Pech $-t V h$ be a member too? The full form $-t V h$ is emphatic, but this marker usually shows up in a reduced form.

(22) Pech (Holt 1999: 5)

Pah-táh-ari. / Pah-t-ari.

touch-NEG-1sG.E.PST

'I didn't touch it.'

This may well be a 'bridge too far', but it is perhaps not farfetched to claim that Pech $-t V h$ is related to the postposed negator of Rama (Votic) taama/tahma.

(23) Rama (Grinevald 1990: 185)

Naas kam-taama.

1sG sleep-NEG

'I don't sleep.'

In Pech the vowel of $-t V h$ assimilates to the following vowel. If the taa of Rama were like $-t V h$, it would be $t a h$ when followed by -ma. Of course, the Rama form is more complicated, as $t V h$ - is followed by - $m a$. This $-m a$ could be related to the negator $m e$ in Terribe (\$2.1.3), Bokotá (\$3.1) and Maléku Jaíka (\$3.4) and - coincidence or not, ma shows up as a negator in a great many languages of Central and South America (Payne 1990: 77; van der Auwera \& Krasnoukhova, Subm; inter alia). ${ }^{13}$ Since Teribe llëme is phonemic / 3 me/, it resembles $t$ Vhma. Of course, this superficial observation begs more questions than it answers.

\subsection{Kuna suli}

The best described dialect of Kuna (Isthmic) is San Blas Kuna. There the main or only standard negator is the clitic $=\operatorname{suli}\left(\right.$ Smith 2014: 169) / chule (Gassó 1908: 89). ${ }^{14}$

(24) San Blas Kuna (Smith 2014: 169)

$\begin{array}{llll}\begin{array}{l}\text { Neg-wagar } \\ \text { place-far }\end{array} & \text { bar } & \text { an } & \text { dako-o=suli. } \\ & \text { 1sG } & \text { see-PRos-NEG }\end{array}$

'I will not see the place anymore.'

In Erice (1980: 163) it is stated that suli is also a privative postposition, a view supported by Holmer (1947: 163), but the latter also glosses it as an existential negator ('there is not').

${ }^{13}$ If Ostler's (1997-1998: 207) Tunebo $b a$ is the same as the one we have referred to as bar, then, according to Ostler (1997-1998: 207), this form is also related to $\mathrm{ma}$.

${ }^{14}$ There are similar forms in Border Kuna (Forster 2011: 206; Llerena Villalobos 1987: 86). 
(25) San Blas Kuna (Erice 1980: 33)

$\mathrm{Be}$ suli kege an nai.

2SG NEG cannot $1 \mathrm{SG}$ go

'I can't go without you'

The su- element shows up in Cogui suñ, suñzē, suñza and súngele. For these markers Preuss (1925: 382) claims that $-z \bar{e}$ comes from an existential verb zeiši and le from another 'be' verb gele. If this is correct, it suggests that suli decomposes as NEG-EX. It further follows that either San Blas Kuna standard negation is done existentially or, if there was ever a stage when it was not done existentially, San Blas Kuna went through a Negative Existential Cycle.

\subsection{Arhuaco and Malayo}

Arhuaco and Malayo are two closely related Magdalenic languages. In Arhuaco the standard negator $-u$ ' on a lexical verb is followed by an auxiliary (Frank 1985: 120-121, 1990: 89-90; Landaburu 1992: 28-29).

(26) Arhuaco (Frank 1985: 8)

Eima kusari an-a-g- $u$ ' nän-na ni.

that deer NHUM.OBJ-1PL-eat-NEG AUX-DIST CERT

'We didn't eat that deer.'

According to Landaburu (1992: 28) the auxiliary is a 'be' verb and the lexical verb is participial. There are five types of participles, each has its suffix (Landaburu 2000: 741). The negator is such a suffix. So, we partially understand why standard negator is postposed: it fits the paradigm of participial suffixes. The 'be' verb seems to serve or have served ascription, as it can mark the subject, as in (27). Its position makes sense too - the language is SOV (Frank 1985: 4)

(27) Arhuaco (Landaburu 1992: 28, 2000: 743)

Chu narwin.

see.NEG be.SG.ASS

'I do not see it'

It appears that the auxiliary is not necessary (Frank 1985: 64, 1990: 47), but it is not clear what the conditions are under which it may be absent (cf. also Miestamo 2005: 290).

In the related language Malayo, there is no auxiliary at all, but not because it is omitted but because it seems to have turned into morphology. The language has three negators sensitive to tense and aspect, viz. un, -ung, -uní, and -ungui (Trillos Amaya 1999: 49; Williams 1993: 90-91).

(28) Malayo (Trilllos Amaya 1999: 49)

a. Zhamai-un-ka. sing-NEG-AFF

'(S)he does not sing' 
b. Zhamai-uní.

sing-NEG.PFV

'(S)he did not sing'

We take it that the Malayo initial $-u$ in each of the negators is the suffix $-u$ from Arhuaco and that what follows, always containing an $-n$, is what remains of the 'be' verb in Arhuaco. But there is no separate ascription anymore, we are just dealing with four standard negators. What we see therefore makes sense as a development from ascriptive negation to standard negation, a scenario that is only recently deserving due attention (Krasnoukhova \& van der Auwera 2019).

\subsection{Interim conclusion}

We have now surveyed the postposed negators of Chibchan. The first thing to note is that there is more than one way that a negator can be postposed to the verb. (29) surveys what we could glean from our sources.

$\begin{array}{ll}\text { (29) } \ldots . \mathrm{V} \ldots \mathrm{NEG}]_{\mathrm{CL}} & \text { Terraba, Teribe } \\ \mathrm{V}=\mathrm{NEG} & \text { Kuna } \\ \text {-NEG }]_{\mathrm{V}} & \text { Arhuaco, Rama } \\ \text {-TA-NEG }]_{\mathrm{V}} & \text { Chibcha } \\ \text {-NEG-TA }]_{\mathrm{V}} & \text { Boruca } \\ \text {-NEG-PERS.TA }]_{\mathrm{V}} & \text { Pech } \\ \text {-NEG-TA-PERS }]_{\mathrm{V}} & \text { Tunebo, Barí, Cogui } \\ \text {-NEG.TA-ILL }]_{\mathrm{V}} & \text { Malayo }\end{array}$

First, the negator may be clause-final, in which case it is also, but trivially so, postposed to the verb. Interestingly, this is the only case in which the negator is a particle and we suggested earlier that this marking may still show a lexical origin and may be therefore relatively recent. In Kuna we may have a postverbal clitic. The other cases have verbal suffixes. On a grammaticalization cline a particle is lower than a clitic and the latter is lower than a suffix. Second, the suffixes may or may not be the absolutely final element in the verb. If not, they can be followed by tense-aspect markers or by both person and tense-aspect markers, in either order, or by an illocutionary marker. As for the relative placement of tense-aspect markers and negative suffixes, it seems that the negative suffixes usually precede the tense-aspect markers. This synchronic variation relates, no doubt, to different origins. For Teribe the negator may go back to the negative indefinite pronoun 'nothing', for Kuna to a negative existential verb, for Tunebo, Barí and Cogui to an adjectival negator and for Arhuaco and Malyao to a participial one, which can be taken as adjectival too.

Second, Boruca -i’shi, Tunebo -ti, Barí -shi, Cogui -zhél-ža or Chibcha -za/-zha/žal $\check{z} \bar{e} / z ̌ i$ may well be related and with a good deal of hesitation one could think that Pech $-t V h$ and the first elements of Teribe llëme and Rama taamma/tahma are related too. However, the hypothesis that that lle is originally 'thing' is far from the nominal negation analysis mentioned for Boruca $-i^{2}$ shi. So while both hypotheses attain a certain plausibility, it is 
impossible to unite them in a unified account, possibly because the various forms are not, after all, cognates, but just look-alikes. At least, this undecidedness puts this matter on the agenda for future research.

A third observation relates to Tunebo. We may here find a case where the language has a circumposed maker, if, at least, we may consider the $-i$ suffix to be (or have become) inherently negative.

A final observation is that postposed negators are found throughout Chibchan. We find them in Pech, Votic, Isthmic as well as Magdalenic.

\section{Preposed negators}

\subsection{Buglere mingiale and ming}

In the Buglere branch of Eastern Isthmic Chibchan there are two languages, viz. Sabanero and Bokotá. Sabanero is described by Jara (1989) and Quesada (2012), the latter being more extensive. For Quesada (2012) standard negation has four negators, viz. mingiale, its two short forms miniale and ming, and occasionally also ning (literally) 'no one' (Quesada 2012: 116-117). The canonical position of the negators is preposed, though not necessarily adjacent to the verb, but rather before the OV verbal complex (Quesada 2012: 117).

(30) Sabanero (Quesada 2012: 118, 124)

a. Ba ming salmong doe cha aling.
2SG NEG salmon bring $1 \mathrm{SG}$ BEN
'You didn't bring me the salmon.'
b. Che maña ning be chige. ${ }^{15}$ 3SG NEG FUT come
'He won't come.'

The long form is also used as an existential negator.

(31) Sabanero (Quesada 2012: 117)

Gidi doia mingiale na.
and already NEG.EX more
'And the enemy no longer exists.'

Jara (1989: 116, 135) gives only two negators, viz. one short form $\min$ for standard negation and one long form mialen for existential negation. mialen is close to the form that Margery Peña (1993: 82) gives in a dictionary, viz. miále, who describes it as a contraction of a negator mín and iále glossed in Spanish as 'no haber'. The contraction itself is also glossed as 'no haber'. We take it that the author has no hay in mind for the resultant meaning, which in English comes out better as 'not exist'. iále probably does not have a

${ }^{15}$ In the source material the gloss ' $3 \mathrm{SG}$ ' corresponds to the complex form che maña. 
negative meaning itself, but it would express existence only in a negative context, different from the positive klebi or a zero 'be' verb, which cannot occur there (Quesada 2012: 117). So mingiale/mialen is most likely a univerbation of a negator and an existence verb. Interestingly, though Quesada (2012: 117) writes mingiale as one word in the example (31), in the surrounding text it is written as two words.

For Bokotá we find Gunn (1975: 90) mentioning two simple standard negators, me as the basic form, illustrated in (32) and $m i$ for the future; both are preposed.

(32) Bokotá (Gunn 1975: 91)

Cha me ñage bla lie dale.

1SG NEG can banana cook in.no.way

'I really can't cook banana.'

For me Gunn also mentions a negative existential use.

(33) Bokotá (Gunn 1975: 9)

Bla me.

banana NEG.EX

'There are no bananas.'

What to make of this? We propose that of the two languages Sabanero is the more progressive one, in the sense that it pushed furthest in the Negative Existential Cycle. Next to simple standard negator $\mathrm{min} / \mathrm{ming}$, corresponding to Bokotá $\mathrm{mi} / \mathrm{me}$, it developed a dedicated existential negator, which it then started using as a standard negator too. ${ }^{16}$ Interestingly, in the prohibitive the ming iale negator makes no inroad; it remains the territory of ming (Quesada 2012: 98). This makes sense: the imperative is an actionoriented construction, and negative existence is a state-oriented construction. Finally, the Sabanero negator ning is intriguing: as mentioned already, ning 'no one' is like Latin non oenum also 'not one', which turned into the standard negator non - another possible manifestation of a Jespersen Cycle.

\subsection{Ngäbere $\tilde{n} a k a$ and related forms}

With Ngäbere we stay in Eastern Isthmic. The language is spoken in Panama but since the 1950's speakers emigrated to Costa Rica. In Panama Ngäbere the default standard negator is ñaka (Quesada Pacheco 2008: 64)

(34) Panama Ngäbere (Quesada Pacheco 2008: 64)

Dwana ñaka nibi nügueta.

son-in-law NEG stay.REC arrive.IND.ITER

'The son-in-law did not return'

${ }^{16}$ Quesada (2012: 117) describes ming as a reduced form ming iale. Another perspective, one that fits our conjecture better, has ming iale as an expanded form of ming. 
There are two longer negators, viz. ñakare and ñäkwäre (Quesada Pacheco 2008: 6569). The latter is exclusively used as a negative existential (35c). The former is used both for standard negation - and then it is preposed (35a) - and for an existential negation - and then it follows the constituent in its scope, if expressed, (35b).

(35) Panama Ngäbere (Quesada Pacheco 2008: 65, 66, 68)
a. Mä ñakare törabai ti kwetai.
$2 \mathrm{SG}$ NEG want.FUT $1 \mathrm{SG}$ eat.FUT
'You won't want to eat me.'
b. Siribi ñakare.
work NEG.EX
'There is no work.'
c. Kä ki dere, dwana ñäkwä nüta, day come.REC late son-in-law NEG arrive.REC.ITER jädrin naine ñäkwäre. next.day early NEG.EX

'It was getting dark, but the son-in-law did not come back, the next day he wasn't there.'

For the Ngäbere of Costa Rica, Murillo Miranda (2016: 77-78) reports similar forms and functions. But there are differences, too. First, standard negation has two additional forms, viz. $\tilde{n} a(n)$ and $\tilde{n} u k w \ddot{a}$. In Panama Ngäbere both forms function as an adversative conjunction ('but not'), the short one has a wider conjunctive use ('and not', 'lest') and it also functions as a prohibitive negator. Second, ñakare (here ñagare) is given a privative characterization - see tö ñagare 'fool' but literally 'without idea' in (36) - and only

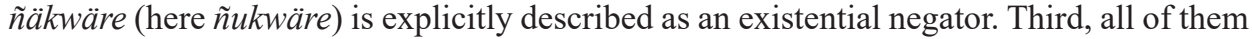
can express negation, the only difference being that ñagare and ñukwäre carry emphasis.

(36) Costa Rica Ngäbere (Miranda Murillo 2016: 78)

Jetébe ti gwe Jaime tö ñagare meta-i.

tomorrow 1SG NOM Jaime idea PRIV hit-FUT.REM

'Tomorrow I will hit that fool Jaime.'

(37) Costa Rica Ngäbere (Miranda Murillo 2016: 78)

Mä ñaka/ñagare/ñan/ñukwäre/ñukwä mütü kwet-e.

2SG NEG

pig eat-PRS

'You don't eat pig.'

A comparison between the two varieties makes us hypothesize that the Costa Rican variety of Ngäbere is the more progressive one, at least with respect to the most complex form, i.e., ñäkwäre/ñukwäre. In Panama it only has an existential use, in Costa Rica it is used as a standard negator, but it is a marked one, for it carries emphasis. Thus, the entry of

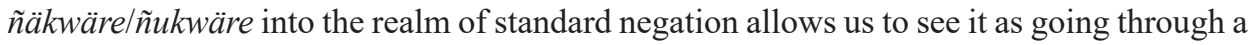


Negative Existential Cycle. The other complex form ñakare/ñagare could be a newcomer too, either also originally an existential negator or perhaps a privative one.

\subsection{Bribri $k \ddot{e}$ and Cabécar $k a ́$}

With Bribri and Cabécar we move to Western Isthmic. In the account of Jara Murillo (2013: 106-108), Bribri has a preposed $k \ddot{e}$ as a standard negation. (38a) illustrates this, and (38b) shows the positive counterpart.

(38) Bribri (Jara Murillo 2013: 107)

a. Ie' kë tsö-kũ.

3SG NEG sing-IPFV.NEG

'He won’t sing.'

b. Ie' tsö-ke.

3SG sing-IPFV

'He will sing.'

A comparison between the negative and the positive version shows that the negative version does not only differ by the presence of the negative $k e ̈$ : the verb is different too: the tense aspect marker is not $k e$ but $k \tilde{u}$. This means either of two things: in case there is nothing inherently negative about $k \tilde{u}$, we are dealing with constructional asymmetry (Miestamo 2005). If kũ is inherently negative, however, negation in Bribri is not preposed but circumposed, at least in the imperfective. The latter analysis is the plausible one. It turns out that $k \tilde{u}$ is also a negative existential or stative verb.

(39) Bribri (Jara Murillo 2013:107)
a. Pё’ kë $k \tilde{u}$ ù ã. people NEG NEG.EX home LOC 'There is nobody home.'
b. Pë' tso' ù ã. people EX home LOC 'There is somebody home.'

How this structure needs to be understood is unclear, though. In a 'normal' Negative Existential Cycle a negative existential impinges on standard negation and replaces it. In (39a) there could be two negators. Negative Existential Cycles with two negators are not unknown, but we usually see that the existential negator is added to the standard negator, initially for emphasis, and that it is the newer negator (cf. van der Auwera; Krasnoukhova $\&$ Vossen 2020: 15-17). In (39a), however, the existential negator is morphological, and the non-existential one is syntactic, suggesting that the existential one is older.

What makes it more complex still, is that $k \ddot{e} \mathrm{~V}-k \tilde{u}$ doubling is not the only negation strategy. In the perfect, shown in (40), $k e$ has constructional asymmetry, with the verb taking up middle morphology, which is not, in any obvious way, inherently negative. Note 
that there is paradigmatic asymmetry: the semantic distinction between recent and remote past is neutralized in the negative.

(40) Bribri (Jara Murillo 2013: 108)
a. Ie' inế.
3SG play.PST.REC
'He played.' (recently)
b. Ie' inĩ'.
3SG play.PST.REM
'He played.' (not recently)
c. Ie〉 kë inî̀nẽ.
3SG NEG play.M.PST.REM
'He didn't play.'

What is also puzzling is that the earlier description of the language by Fábrega (1898: 50 ) identifies the negator as a clause-initial $k i$.

In Cabécar the situation is somewhat similar. At least, there is a preposed particle $k a ́$ and in some tense-aspect settings there is also a negative existential auxiliary kúnã, which is a suppletive form different from the positive existential verb tsõ (Margery Peña 1985, 1989).

(41) Cabécar (Margery Peña 1985: 107; 1989: lxviii; 1989: 120)
a. Yís ká ttö
ijéwá ra.
1SG NEG speak.IPF.IND 3PL with
'I don't speak with them.'
b. Bá chéga ká kứnã díglö ska.
2SG friend NEG NEG.EX river in
'Your friend is not in the river.'
c. Yís kuta ká ksö kứnã.
$1 \mathrm{SG}$ sister NEG sing NEG
'My sister was not singing.'

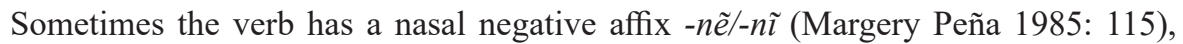
which might derive from the negative existential auxiliary.

(42) Cabécar (Margery Peña 1985: 115)

$\begin{array}{lllllll}K a ́ & \text { ijéwá } & \text { wã } & \text { nấglö } & \text { mế-nẽ } & \text { yís } & \text { iã. } \\ \text { NEG } & \text { 3PL } & \text { ERG.NEG } & \text { money } & \text { give.PST.REM-NEG } & 1 \mathrm{SG} & \text { to }\end{array}$

'They didn't give me money.'

Example (42) also shows that the ergative has a dedicated negative form wã different from the positive të and that $k a ́$ is not restricted to the immediate preverbal position. Like 
for Bribri, it is not clear whether the markers associated with the definitely negative $k \dot{a}$ show constructional asymmetry or double and even triple exponence.

\subsection{Other markers}

What is interesting about Maléku Jaíka is that it has two preposed particles, viz. épe $($ also $=p e)$ and éme $($ also $e m=$ and $=m e)$ and they can also occur together as epéme, which tends to make the negation stronger (Constenla Umaña 1998: 26, 163-164)

(43) Maléku Jaíka (Constenla Umaña 1998: 164)

Epéme rricuánhe.

NEG (3).3ERG.see.R

'He didn't see it.'

Also of interest is that these particles are not just preposed, but clause-initial (Constenla Umaña 1998: 163). It compares to Teribe in the postposed domain: the Teribe negator is not just postposed but clause-final. Finally, note that we meet me again (see $\S 2.1 .3$ and $\$ 2.1 .4)$.

In Chimila (Magdalenic) the negator is jumma. Trillos Amaya (1996: 162-163) points out that it sometimes takes a subject marker, and the author sees this as a reason for a tentative hypothesis that jumma has a verbal status.

(44) Chimila (Trillos Amaya 1996: 162)
a. Jumma juny-a Maria. NEG walk-IPFV Maria
'Maria doesn't walk.'
b. Jumma-na juny-a. NEG-1sG walk-IPFV
'I don't walk'

If jumma is a verb, we may perhaps understand its clause-initial position. Chimila is SVO (Adelaar with Muysken 2004: 79), though pronominal subjects appear as verbal suffixes and then the sentence starts with the verb. Also, the final $-a$ on the lexical verb, glossed as 'imperfective' by Trillos Amaya (1996), is suspicious: for constructions with auxiliaries Adelaar with Muysken (2004: 76) propose that it might well be a nominalizer.

Finally, we come to Votic Rama. Rama was already mentioned in $\$ 2.1 .4$, because of its postposed taama/tahma, but the language also has two preposed particles, viz. aa and yaana (Grinevald 1990: 183, 190). Neither has to occur immediately before the verb.

(45) Rama (Grinevald 1990: 183, 190.)
a. Nkiikna-lut $a a$ uut kain-i.
man-PL NEG dory make-T
'The man doesn't make a dory' 

b. Yaana urnga ma-ni-tang.
NEG food 2-1-give
'I am not going to give you food.'

\subsection{Interim conclusion}

We can now summarize the findings on proposed negators and compare with what we have observed for postposed negators. Thus, like postposed negators the preposed negators show a fair amount of variation. Just like 'postposed' negators can be clausefinal, 'preposed' ones can be clause-initial, cf. Maléku Jaíka épe, éme, epéme and Bribri $k i$ (in the description of Fábrega 1898). 'Preposed' negators can be adjacent to the verb, but they can also allow other material in between, cf. the negators of Buglere. This is in parallel with the variation in the position of the postposed negator relative to the verbal root. We may also have circumposition, cf. Bribri kë V-kũ and Cabécar ká V kû́nã, but it is rather marked, just like it was in the postposed domain. For the postposed domain we appealed to diachrony involving existential negators and a negative indefinite. We do this here too: negative existentials as a source is hypothesized for Sabanero, Bokotá, Ngäbere, Bribri and Cabécar, and an indefinite origin was mentioned for Sabanero ning 'not one'.

There are differences too. Thus, we see univerbation of two negators in Maléku Jaíka, and the negator in Chimila might be a verb. The biggest difference is that the preposed negators are nearly all free standing elements, mostly particles and perhaps a verb in one language (Chimila), whereas the postposed ones are nearly all suffixal. This difference is found in South America as a whole (Krasnoukhova \& van der Auwera, subm.) and, in fact the world as a whole (Dahl 1979: 94; Dryer 2013). There is yet another difference. The postposed negators seem typical of the Magdalenic branch languages but are, in fact, found in all other branches too. The preposed ones, on the other hand, are concentrated in Votic and Isthmic, and found only in one language outside these branches (Chimila). We will come to this difference in the next section.

\section{Overview of the negation markers}

Table 2 lists the negation markers discussed in this paper. The languages and families are listed in an order going from the North to the South and from the West to the East. 
LIAMES 20

Table 2: Negation in Chibchan languages

\begin{tabular}{|c|c|c|c|c|c|c|}
\hline \multirow{2}{*}{ Brench } & \multirow{2}{*}{ Language } & \multicolumn{2}{|c|}{ Preposed } & \multirow[t]{2}{*}{ Circumposed } & \multicolumn{2}{|c|}{ Postposed } \\
\hline & & Clause-initial & Preposed & & Postposed & Clause-final \\
\hline Non-core & Pech & & & & $-t V h$ & \\
\hline \multirow[t]{2}{*}{ Votic } & Rama & yaana & $a a$ & & taama & \\
\hline & $\begin{array}{l}\text { Maléku } \\
\text { Jaíka }\end{array}$ & $\begin{array}{c}\text { éme } \\
\text { épe } \\
\text { epéme }\end{array}$ & & & & \\
\hline \multirow{4}{*}{$\begin{array}{l}\text { West } \\
\text { Isthmic }\end{array}$} & Cabécar & & $k a ́$ & ká .. kuna & & \\
\hline & Bribri & $k i$ & $k \ddot{e}$ & $k \ddot{e} \ldots \mathrm{V}-k \tilde{u}$ & & \\
\hline & Teribe & & & & & lléme \\
\hline & Boruca & & & & $-i^{2} s h i$ & \\
\hline \multirow{4}{*}{ East Isthmic } & Ngäbere & & naka & & & \\
\hline & Sabanero & & ming iale & & & \\
\hline & Bokotá & & $\begin{array}{c}\text { miale } \\
\text { me }\end{array}$ & & & \\
\hline & Kuna & & & & -suli & \\
\hline \multirow{4}{*}{$\begin{array}{c}\text { North } \\
\text { Magdalenic }\end{array}$} & Chimila & & jumma & & & \\
\hline & Cogui & & & & $\begin{array}{c}-z h e ́ \\
-k i\end{array}$ & \\
\hline & Arhuaco & & & & $-u$ & \\
\hline & Malayo & & & & $-u$ & \\
\hline \multirow{3}{*}{$\begin{array}{c}\text { South } \\
\text { Magdalenic }\end{array}$} & Chibcha & & & & $-z(h) a$ & \\
\hline & Barí & & & & $-s h i$ & \\
\hline & Tunebo & & & $-i \ldots-t i$ & $\begin{array}{c}-t i \\
-b a r\end{array}$ & \\
\hline
\end{tabular}

As observed in $\$ 3.5$, preposed negation is mostly found in the North, i.e., in Votic and Isthmic - though not in Pech. If Constenla Umaña (1991: 111) is right, Meso-America is predominantly preposed (though Campbell et al. 1986, van der Auwera 1998 or Munro 2017 do not consider the position of the negator in their analyses of the Meso-America as a linguistic area). Further north is, to wit, North America and for this large area Vossen (2016: 321) argues that it prefers the preposed negation. So it would make 'areal sense' to see the North of Chibchan connecting with Meso-America and North America. Second, postposed negation is found throughout Chibchan (cf. §2.4) but because of the near-absence of preposed negation here, it is more strongly associated with the South. According to Constenla Umaña (1991: 111) the northern part of South America is mixed with respect to the position of negation. So there is no strong areality here. However, it is true that South 
America as a whole has an unusually high percentage of postposed negators (Muysken et al. 2014: 305-306; Vossen 2016: 321).

There are several markers that show up both in the North and the South, suggesting that they are very old. Thus, $i$ s shi/-ti/shi forms are mostly Magdalenic, but Boruca is Isthmic and perhaps the $t$ - forms in Pech and Rama are cognates, too. $m e$ and $m a$ forms show up in two branches, too. The $k$ - forms are essentially West Isthmic, but Cogui has a $k i$ form as well. Finally, there are some forms (like Rama yaana) that are unique to a language.

\section{Conclusion}

We described the variation in both the form and the position of standard negators in the Chibchan languages, based on published sources. The clearest result is that the characterization of Chibchan as having predominantly postposed negators is not correct. There is, instead, a great deal of variation. Also, within the set of languages that have either postposed or preposed negators there is a good amount of variation. As an indicator of belonging to the Columbian Central American linguistic area, the position of the standard negators does not fare well. Nevertheless, we have shown that within Chibchan the position of standard negators is not areally random, with the North preferring preposed negators and the South preferring postposed negators. The North-South division is, however, also a genealogical one, with Isthmic in the North and Magdalenic in the South.

The variation in the form and the position of the standard negators, so much is obvious, must relate to different origins. We hope to have shed some light on these origins, not through direct diachronic analysis, but through making sense of synchronic variation, aided by the typological literature on what is known to be pathways for the development of negation. We have made suggestions on the relevance of both the Jespersen and the Negative Existential Cycle. However, much remains tentative or even unclear. In that way, this paper asked as many questions as it provided elements of answers, and it counts as an invitation for further research. 


$\begin{array}{llll}\text { Abbreviations } & & \\ 1 & \text { first person } & \text { IPFV } & \text { imperfective } \\ 2 & \text { second person } & \text { ITER } & \text { interative } \\ 3 & \text { third person } & \text { LOC } & \text { locative } \\ \text { A } & \text { aspect } & \text { M } & \text { masculine } \\ \text { AFF } & \text { affirmative } & \text { N- } & \text { non- } \\ \text { ASS } & \text { assertion } & \text { NEG } & \text { negation } \\ \text { AUX } & \text { auxiliary } & \text { NMLZ } & \text { nominalization } \\ \text { BEN } & \text { benefactive } & \text { NOM } & \text { nominative } \\ \text { CERT } & \text { certitude } & \text { OBJ } & \text { object } \\ \text { CL } & \text { clause } & \text { PART } & \text { partitive } \\ \text { CONT } & \text { contrastive } & \text { PERS } & \text { person } \\ \text { DEM } & \text { demonstrative } & \text { PFV } & \text { perfective } \\ \text { DET } & \text { determiner } & \text { PL } & \text { plural } \\ \text { DIST } & \text { distal } & \text { POSIT } & \text { position } \\ \text { E } & \text { early } & \text { PRIV } & \text { privative } \\ \text { ERG } & \text { ergative } & \text { PROS } & \text { prospective } \\ \text { EX } & \text { existential } & \text { PRS } & \text { present } \\ \text { EXCL } & \text { exclusive } & \text { PST } & \text { past } \\ \text { FUT } & \text { future } & \text { R } & \text { realis } \\ \text { HUM } & \text { human } & \text { REC } & \text { recent } \\ \text { ILL } & \text { illocution } & \text { REM } & \text { remote } \\ \text { IMP } & \text { imperative } & \text { SG } & \text { singular } \\ \text { INCL } & \text { inclusive } & \text { T } & \text { tense } \\ \text { IND } & \text { indicative } & \text { V } & \text { verb } \\ \text { INT } & \text { interrogative } & & \\ & & & \end{array}$

\section{References}

Adelaar, Willem F. H.; Pieter C. Muysken (2004). The Languages of the Andes. Cambridge: Cambridge University Press.

Campbell, Lyle; Terrence Kaufman; Thomas C. Smith-Starke (1986). Meso-America as a linguistic area. Language 62: 530-570.

Celedón, Rafael (1886). Gramática de la Lengua Köggaba con Vocabularios y Catecismos. Paris: Maisonneuve $\&$ Leclerc.

Constenla Umaña, Adolfo (1991). Las lenguas del área intermedia: Introducción a su estudio areal. San José: Universidad de Costa Rica. SaS

Constenla Umaña, Adolfo (1998). Gramática de lengua Guatusa. Heredia, Costa Rica: EUNA.

Constenla Umaña, Adolfo (2012). Chibchan languages. In Lyle Campbell; Verónica Grondona (eds.), The Indigenous Languages of South America: A Comprehensive Guide, pp. 391-440. Berlin: Mouton. 


\section{VAN DER AUWERA \& KRASNOUKHOVA - STANDARD NEGATION...}

Croft, William (1991). The evolution of negation. Journal of Linguistics 27:1-27. doi: https://doi.org/10.1017/S0022226700012391

Dahl, Östen (1979). Typology of sentence negation. Linguistics 17: 79-106.

Dryer, Matthew (2013). Order of negative morpheme and verb. In Matthew Dryer; Martin Haspelmath (eds.), The World Atlas of Language Structures Online. Retrieved from at http://wals.info/chapter/143A (Accessed 10/09/2019.)

Erice, Jesús (1980). Gramática de la lengua kuna. Panamá: Instituto Nacional de Cultura.

Fábrega, Henry Pittier de (1898). Die Sprache der Bribri-Indianer in Costa Rica. Wien: Carl Gerold's Sohn.

Forster, D. Keith (2011). Paya Kuna: An introductory grammar. SIL International. https://www.sil.org/resources/archives/41525

Frank, Paul Stephen (1985). A grammar of Ika (Chibchan, Colombia) (Doctoral dissertation). Philadelphia: University of Pennsylvania,

Frank, Paul (1990). Ika syntax (Studies in the languages of Colombia 1). Dallas: Summer Institute of Linguistics. https://www.sil.org/resources/publications/entry/8925

Gassó, Leonardo (1908). Gramática Karibe-Cuna. Barcelona: Tipografía Católica.

Grinevald, Colette G. (1990). A grammar of Rama. Report to the National Science Foundation.

Gunn, Robert D. (1975). La oración sencilla en bokotá. In Stephen H. Levinsohn (ed.), Observaciones preliminares sobre los sistemas gramaticales de las lenguas chibchas, pp. 83-135. Panamá: Instituto Nacional de Cultura and Instituto Lingüístico de Verano.

Hamari, Arja; LjubaVeselinova (eds.) (2020). The negative existential cycle from a historical-comparative perspective. Berlin: Language Science Press.

Hammarström, Harald; Robert Forkel; Martin Haspelmath (2019). Glottolog 4.0. Jena: Max Planck Institute for the Science of Human History. Retrieved from http://glottolog.org, (Accessed 28/8/2019.)

Headland, Edna R. (1994). Diccionario bilingüe Tunebo-Español, Español-Tunebo con una breve gramática tuneba (MA thesis). Arlington: University of Texas.

Holmer, Nils M. (1947). Critical and comparative grammar of the Cuna language. Göteborg: Etnografiska Muséet.

Holmer, Nils M. (1953). Contribución a la lingüística de la Sierra Nevada de Santa Marta. Revista colombiana de antropología 1: 311-355.

Holt, Dennis (1999). Pech (Paya). München: Lincom.

Jara Murillo, Carla Victoria (1989). Categorías en el sistema verbal del bocotá de Chiriquí. Estudios de Lingüistica Chibcha 8: 105-139. https://revistas.ucr.ac.cr/index.php/chibcha/article/view/17673 
Jara Murillo, Carla Victoria (2013). Morfología verbal de la lengua bribri. Estudios de Lingüística Chibcha 32: 95-152. https://revistas.ucr.ac.cr/index.php/chibcha/article/view/17594/17091

Krasnoukhova, Olga \& Johan van der Auwera (2019). From ascriptive negation to standard negation. Paper presented at 13th International Conference of the Association for Linguistic Typology, Pavia, September 2019.

Krasnoukhova, Olga \& Johan van der Auwera (Subm.). Negation in South American languages: A typological overview. Manuscript submitted for publication.

Landaburu, Jon (1992). La Langue Ika ou Arhuaco: Morphosyntaxe du Noyau Verbal de l’Énoncé”. Amerindia $17: 1-30$.

Landaburu, Jon (2000). La Lengua Ika. In Maria Stella González de Pérez; María Luisa Rodríguez de Montes (eds.), Lenguas indigenas de Colombia: Una visión descriptiva, 733-748. Santafé de Bogotá: Instituto Caro y Cuervo.

Llerena-Villalobos, Rito (1987). Relación y determinación en el predicado de la lengua kuna. Bogotá: Centro colombiano de estudios en lenguas aborígenes.

Margery Peña, Enrique (1985). Morfología flexiva del verbo cabécar. Estudios de Lingüistica Chibcha 4: 101-154. https://revistas.ucr.ac.cr/index.php/chibcha/article/view/24981

Margery Peña, Enrique (1989). Diccionario Cabécar-Español, Español-Cabécar. Editorial de la Universidad de Costa Rica.

Margery Peña, Enrique (1993). Vocabulario bocotá. Estudios de Lingüistica Chibcha 12: 53-93. https://revistas.ucr.ac.cr/index.php/chibcha/article/view/30024

Márquez, María Elena; Esperanza (Berichá) Aguablanca \& Jesús Olza (1988). Gramática de la lengua tuneba: morfosintaxis del Cobaría. San Cristóbal: Universidad Católica del Tachira.

Michael, Lev (2014). A typological and comparative perspective on negation in Arawak languages. In Lev Michael; Tania Granadillo (eds.), Negation in Arawak languages, pp. 241-300. Leiden: Brill.

Miestamo, Matti (2005). Standard negation. The negation of declarative verbal main clauses in a typological perspective. Berlin: Mouton de Gruyter.

Munro, Pamela (2017). The Mesoamerican linguistic area revisited. In Karen Dakin; Claudia Parodi \& Natalie Operstein (eds.), Language contact and change in Mesoamerica and beyond, pp. 335-351. Amsterdam: Benjamins.

Murillo Miranda, José Manuel (2016). Gramática de la lengua guaymí. Dialecto de Costa Rica: Una descripción urgente. Saarbrücken: Editorial Académica Española.

Muysken, Pieter; Harald Hammarström; Joshua Birchall; Swintha Danielsen; Love Eriksen; Ana Vilacy Galucio; Rik van Gijn; Simon van de Kerke; Vishnupraya Kolipakam; Olga Krasnoukhova; Neele Müller; Loretta O'Connor (2014). The languages of South America: deep families, areal relationships, and language contact. In Loretta O'Connor; Pieter Muysken (eds.), The native languages of South America. Origins, development, typology, pp. 299-322. Cambridge: Cambridge University Press. 


\section{VAN DER AUWERA \& KRASNOUKHOVA - STANDARD NEGATION...}

Ortíz Ricaurte, Carolina (1992). La predicación en la lengua kogui. In Lenguas aborígenes de Colombia, Memorias 2: 117-125.

Ortíz Ricaurte, Carolina (1994). Clases y tipos de predicados en la lengua kogui. Bulletin de l'Institut Français d'Études Andines 23: 377-399.

Ostler, Nicholas (1997-1998). El idioma chibcha y sus vecinos - Vista genética y tipológica. Estudios de Lingüistica Chibcha 16-17: 197-217.

https://revistas.ucr.ac.cr/index.php/chibcha/article/view/17648

Oyala Perdomo, Noel (2000). Descripción preliminar del sistema verbal de la lengua Kogui (o Kawgi). In Maria Stella González de Pérez; María Luisa Rodríguez de Montes (eds.), Lenguas indígenas de Colombia: una visión descriptiva, pp. 781-787. Santafé de Bogotá: Instituto Caro y Cuervo.

Payne, David L. (1990). Some widespread grammatical forms In South American Languages. In Doris L. Payne (ed.), Amazonian Linguistics. Studies in Lowland South American languages, pp. 75-87. Austin: University of Texas Press.

Payne, John R. (1985). Negation. In Timothy Shopen (ed.), Language typology and syntactic description, vol. I. Clause structures, pp. 97-242. Cambridge: Cambridge University Press.

Portilla Cháves, Mario (1986). Un caso de muerte de lenguas: El térraba. Estudios de Lingüística Chibcha 5: 97-246. https://revistas.ucr.ac.cr/index.php/chibcha/article/view/17697

Portilla Cháves, Mario (2003). Un manuscrito de Terraba del sigle XIX. Lingüística Chibcha 22: 7-32. https://revistas.ucr.ac.cr/index.php/chibcha/article/view/15222

Preuss, Karl Theodor (1925). Das Verbum in der Sprache der Kágaba in der Sierra Nevada de Santa Marta, Kolumbien, auf Grund meiner Textaufnahmen. In Congrès international des Américanistes : Compterendu de la 21:e session : Deuxième partie tenue à Göteborg en 1924, pp. 348-387. Göteborg: Göteborgs museums etnografiska avdelning.

Quesada, J. Diego (2000). A grammar of Teribe. München: Lincom.

Quesada, J. Diego (2004). The Barí language of Venezuela: A Glimpse at the Chibchan Periphery. Sprachtypologie und Universalienforschung 57: 362-376.

Quesada, J. Diego (2007). The Chibchan languages. Cartago: Editorial Tecnológica de Costa Rica.

Quesada, Juan Diego (2012). Gramática del buglere. Quito: Abya-Yala.

Quesada Pacheco, Miguel Ángel (2008). Gramática de la lengua guaymí (ngäbe). München: Lincom.

Quesada Pacheco, Miguel Ángel (2012). Esbozo gramatical de la lengua Muisca. Estudios de Lingüistica Chibcha 31: 7-92.

Quesada Pacheco, Miguel Ángel (2018). Gramátia boruca. München: Lincom.

Rivet, Paul (1924). La Langue Tunebo. Journal de la Société des Américanistes 16: 19-92.

Smith, Wikaliler Daniel (2014). A grammar of Guna: A community-centered approach. (Doctoral dissertation.) Austin: University of Texas. https://repositories.lib.utexas.edu/handle/2152/25999 
Trillos Amaya, María (1996). Categorias grammatical del Ette Taara: lengua de los chimilas. Bogotá: CESOCCELA, Universidad de los Andes.

Trillos Amaya, Maria (1999). Damana. München: Lincom.

van der Auwera, Johan (1998). Revisiting the Balkan and Meso-American linguistic areas. Language Sciences 20: 259-270. https://doi.org/10.1016/S0388-0001(98)00003-5

van der Auwera, Johan; Olga Krasnoukhova (2020). The typology of negation. In Viviane Déprez; M. Teresa Espinal (eds.), The Oxford Handbook of negation, pp. 91-116. Oxford: Oxford University Press.

van der Auwera, Johan; Olga Krasnoukhova; Frens Vossen (2020). Intertwining the negative cycles. In Arja Hamari; Ljuba Veselinova (eds.), The Negative Existential Cycle from a historical-comparative perspective. pp. 1-41. Berlin: Language Science Press.

van der Auwera, Johan; Olga Krasnoukhova (Subm.). Negative ma in South America with a focus on its standard negative postposed $m a$ in Panoan, Takanan and Tukanoan.

van der Auwera, Johan; Lauren Van Alsenoy (2016). On the typology of negative concord. Studies in Language 40: 473-512. https://doi.org/10.1075/sl.40.3.01van

Veselinova, Ljuba (2014). The negative existential cycle revisited. Linguistics 52:1327-1369. https://doi.org/10.1515/ling-2014-0021

Vossen, Frens (2016). Towards a typology of the Jespersen Cycles (Doctoral dissertation.). Antwerp: University of Antwerp.

Williams, Cindy (1993). A grammar sketch of Dəməna (MA thesis.). Grand Forks: University of North Dakota.

Received: 14/2/2020

Revised and corrected version: 10/4/2020

Article accepted: 16/4/2020.

LIAMES, Campinas, SP, v. 20, 1-27, e020005, 2020 